\title{
Assessment in Initial Teacher Education Views of Portuguese and Polish Students
}

DOI: 10.47050/66515314.54-85

Cláudia Pinheiro, Maria Assunção Flores, Joanna Madalińska-Michalak

Drawing upon a wider piece of research, this chapter ${ }^{1}$ focuses on assessment in teacher education programmes. It reports on data collected in five Portuguese public universities and four Polish public universities. In total, 789 student teachers participated in the study. It aims at investigating student teachers' ideas associated with assessment and the most used methods of assessment considering their experience in teacher education. The participants reported more ideas associated with a summative purpose of assessment than ideas related to a formative purpose in both countries. As for the assessment methods, the data suggest that Portuguese students are assessed using a greater variety of methods, while Polish students highlight mainly the use of methods such as written tests/exams, group projects and group oral presentations.

Keywords:

assessment

higher education

student teachers

methods of assessment

teacher education

1 The project reported in this chapter was funded by the Portuguese Foundation for Science and Technology - FCT, Government Funding Agency (SFRH/BD/122094/2016). 


\section{Introduction}

Students' motives, expectations and preparedness for higher education not only affect how they approach learning tasks, but they also impact on how students adjust to the wider higher education environment (Byrne \& Flood, 2005). Understanding the nature and purpose of teaching and learning entails the consideration of the social, political, cultural and economic contexts in which they are embedded (Flores, 2016a). A look at existing international literature on teaching and learning reveals some common trends; for example, a growing emphasis on issues of accountability and an outcome-led orientation, but also diverse modes of government intervention, different strategies and learning environments, and various understandings of assessment and improving teaching and learning quality (Flores, 2016a; Flores, 2011; Darling-Hammond, Newton \& Wei, 2010).

A diverse and heterogeneous population of students requires changes in teaching practice, with less focus on teacher-centred approaches and more on the learning outcomes that students have to achieve (Sally, 2005; Miller et al., 1998; Rust, 2002) in line with a more student-centred perspective (Flores, 2019b; Myers \& Myers, 2015; Webber, 2012; Kahl \& Venette, 2010; Black \& Wiliam, 1998). Different reasons (motivating students, encouraging activity, providing guidance and feedback, rating and selection) will have an impact on the choice of assessment instruments, which may include a wide variety of methods suitable for different contexts and purposes (Sally, 2005). In this chapter, Portuguese and Polish student teachers' views of assessment are presented.

The present chapter aims (1) to get to know the ideas associated with assessment and methods of assessment used in teacher education; (2) to identify the ideas that Portuguese and Polish student teachers associate with assessment, taking their experience into account; and (3) to identify the methods used in Portuguese and Polish teacher education, taking student teachers' experience into account.

The study is part of a larger research project entitled The use of alternative methods of assessment in higher education: A study of university teacher and students funded by the Foundation for Science and Technology (SFRH/BD/122094/2016) and it was approved by the Ethics Committee on Research on Social and Human Sciences of the University of Minho (SECSH 037/2016). 


\section{Assessment in Higher Education}

Assessment is at the core of teaching and learning in higher education. It is highly influential in shaping the learning experience of students (Thomas et al., 2019; Ramsden, 2003). The central role that assessment plays in learning and teaching is increasingly being recognised in higher education (Hughes, 2011) because the ways in which students are assessed can really make a difference in the way they learn (Sally, 2005). Assessments are used to investigate what people know and can do and to make decisions regarding whether they have learnt what was expected (Baird, 2017).

It is assumed that assessment in higher education faces a number of challenges (Carless, 2007). One of the core problems is that assessment is about several things at once (Ramsden, 2003), or what Boud (2000) refers to as "double duty". It is about grading and learning; it is about evaluating student achievements and teaching them better; it is about standards and invokes comparisons between individuals; it communicates explicit and hidden messages (Carless, 2007). Assessment, thus, engenders tensions and compromises (Carless, 2007). Many current assessment practices do not promote independent, reflective, critical learners and this focus is incompatible with current academic aims (Freeman, 1995; Boud, 1990). In other words, the external pressures on higher education may cause assessment to assume a primarily summative function. Because it is viewed by policy makers as an agent of educational reform (Linn, 2000), comparisons and generalisations on the basis of derived data are a logical consequence (Maclellan, 2004).

Students should have the ability to self-regulate their own learning, internally motivate themselves when no external forces are present, and be able to tap into deep learning approaches and strategies (Byrne et al., 2010; Malan, 2014). Educators need to create environments where students can develop lifelong learning skills. This requires the use of different forms of learning tools through intentional interventions (Malan \& Stegmann, 2018; Hassan, Fox \& Hannah, 2014; Vickerman, 2009).

The distinction between formative and summative assessment is not easy to make (Hernández, 2012; Knight \& Yorke, 2003; Brown et al., 1997). The key difference between these two types of assessment is not when they are used but their purpose and the effect that 
these practices have on students' learning. Some assessments in higher education are designed to be both formative and summative (Hernández, 2012; Yorke, 2007; Taras, 2005; Knight \& Yorke, 2003). Such assessment tasks are considered formative because they provide feedback so that the students can learn from them. Furthermore, the same assessment task fulfils a summative function because a grade is awarded and contributes to the overall results of the course (Knight \& Yorke, 2003; Heywood, 2000). The different purposes of assessment overlap or, at times, are in conflict with each other (Hernández, 2012; Bloxham \& Boyd, 2007; Brown et al., 1997).

Much has been written about the purposes served by assessment in higher education (Liu \& Carless, 2006; Boud \& Falchikov, 2005; Boud, 2000; Peterson \& Irving, 2008). Firstly, a common goal of assessment is to provide students with a certification of achievement (Broadfoot \& Black, 2004). This view of the assessment of learning has long been associated with more summative means of assessment practice (Boud \& Falchikov, 2006). Another purpose of assessment in higher education is to facilitate and to guide student learning. From this perspective, assessments allow lecturers to assess and improve teaching as well as help students manage personal learning processes (Thomas, 2019; Villarroel et al., 2018; Wiliam, 2007). In this formative perspective of the assessment, the literature presents three principles that are believed to support student learning through assessment. Firstly, assessment tasks are learning-oriented (Wicking, 2020; Turner \& Purpura, 2016; Jones \& Saville, 2016; Carless, 2011). There is also a variety of tasks that are used in order to assess achievement with a multiplicity of methods. Secondly, students are encouraged to engage with feedback (Wicking, 2020; Crisp, 2012; Nicol \& Macfarlane-Dick, 2006), which is rich in detail and comes from both formal and informal sources. Thirdly, students' expertise in assessing their own (and others') performance is developed through such means as peer-assessment (Patchan, Schunn \& Clark, 2018; Li \& Gao, 2016; Li, Liu \& Steckelberg, 2010; Li, Liu \& Zhou, 2012; Falchikov, 2007) and self-assessment (Li, 2018; Hill, 2016; Brown, Dewey \& Cox, 2014; Ryan \& Ryan, 2013; Bourner, 2003; Zimmerman, 2002; Dochy, Segers \& Sluijsmans, 1999). However, it is possible that the implementation of formative assessment practices would be problematic with students raised in a culture where such practices are uncommon (Wicking, 2020). 
Student-centred assessment has been widely discussed in recent years, being considered a practice that is increasingly valued in higher education (Webber, 2012) and associated with the evaluation component of effective pedagogy (Myers \& Myers, 2015). This perspective is based on fundamental aspects such as constructive and timely feedback, the student's active and autonomous role (Webber, 2012; Sluijsmans, Dochy \& Moerkerke, 1999; Sambell \& McDowell, 1998), the use of higher-order thinking (Light \& Cox, 2003; Falchikov, 2005), problem-solving and competencies development in real contexts (Dochy, Segers, \& Sluijsmans, 1999). At the same time, studentcentred assessment promotes collaborative learning between students and teachers, allowing them to understand how their learning is taking place (Webber, 2012), enabling more effective learning (Struyven et al., 2005; Tang et al., 1999; Birenbaum \& Feldman, 1998; Sambell \& McDowell, 1998) and allowing self-regulation with effects on students' performance and their approach to learning (Pereira \& Flores, 2019; Pereira, Flores, Veiga Simão \& Barros, 2016; Boud \& Falchikov, 2007; Huba \& Freed, 2000).

Assessment methods and approaches need to be focused on evidence of achievement rather than the ability to convey information. To be valid, the assessment needs to focus on what is intended to be learnt as well. If we want our students to demonstrate employability when they graduate, our assessments need to be designed to be practice-oriented (Sally, 2005). The methods used need to be authentic, that is, assessing what they claim to assess, not just what is easy to assess (ibidem). Any assessment strategy needs to be efficient (Brown et al., 1994). Assessment tasks need to be an integral part of the learning process, as well as feedback. The moment in which assessment occurs is a key issue, since the answers given to the assessed work need to allow opportunities for correction, improvement and future learning (Sally, 2005). Current literature on assessment argues that the process should be a transparent one, with criteria that are explicit and clear to all concerned (assessors and assessed) from the outset (Sally, 2005; Thorpe, 2000; Brown \& Glasner, 1999; Gibbs \& Rowntree, 1999).

Although traditional methods are effective in some contexts and for given purposes, they may not be suitable for all purposes of assessment and may encourage only the reproduction and memorisation of knowledge (Pereira \& Flores, 2019; Perrenoud, 1999; Biggs, 2003). 
Thus, the use of given assessment methods, their adequacy to teaching and learning's goals and the nature of the courses are of paramount importance. According to the literature, non-traditional methods of assessment have emerged especially to overcome less successful aspects in traditional assessment methods.

It is important to understand how assessment practices are viewed in a constructive way, and not just as judgments. Summative feedback, which enables judgments to be made for progression and completion, needs quite clearly and overtly to report to the assessment criteria and to be strongly aligned to the curriculum objectives (Sally, 2005). On the other hand, formative feedback is crucial. It needs to be detailed, comprehensive, meaningful to the individual, fair, challenging and supportive, which is a tough task for busy academics (ibidem).

Learning from feedback is something that can cause anxiety in students and teachers. Teachers spend a significant amount of time developing feedback for students, and it can be frustrating when it appears that they are not reading or acting on those comments. Students who receive feedback do not necessarily have the emotional and strategic competencies to process and implement feedback to develop their learning. For feedback to be effective (Ramon-Casas, 2019; Hughes, 2011; Nicol \& Macfarlane-Dick, 2006), it is necessary to use some simple strategies that increase its impact without increasing the amount of feedback that is given (Allal, 2019; Panadero, Jonsson \& Botella, 2017; Panadero, Jonsson \& Strijbos, 2016). Some of the potential benefits in learning and development reported in the international literature include increased autonomy, motivation (Brown, 2004; Pope, 2001), student responsibility (Somervell, 1993), critical thinking and interpersonal skills aimed at deepening the understanding of the evaluation criteria and achieving quality performance (Dochy, Segers, \& Sluijsmans 1999; Patri, 2002). Thus, by providing adequate and timely feedback to students (Gibbs, 1999), it is possible to improve learning outcomes (Li \& Gao, 2016; Li \& Steckelberg 2005; Pope, 2001). This is even more relevant in teacher education programmes in so far as student teachers will also need to learn from assessment as they will be teachers in the future. 
Initial teacher education:

\section{Key topics in international literature}

Globalisation and internationalisation are two prominent features that influence teacher education (Gray, 2010). Initial Teacher Education (ITE) has been discussed from a wide range of perspectives, focusing on its structure and curriculum, field experiences and coursework and the interplay between them, as well as the learning experiences of student teachers (Flores, 2017; Flores, 2016b; Townsend, 2011; Darling-Hammond, Newton \& Wei, 2010).

A look at the international literature reveals a number of restructuring processes in ITE taking place in different countries such Russia (Valeeva \& Gafurov, 2017), Hong Kong (Goodwin, 2012), the Netherlands (Hammerness, Tartwijk \& Snoek, 2012), Australia (Mayer, Pecheone \& Merino, 2012), the USA (Darling-Hammond, 2012; Imig, Wiseman \& Imig, 2011) and Portugal (Flores, 2011). An analysis of this literature suggests that teaching practice in ITE varies not only in terms of location in the different programmes and their length but also in regard to its philosophy, aims and assessment methods (Flores et al., 2016). Thus, it is possible to identify different "practices" in ITE curricula internationally and diverse ways of articulating them with other components of the programmes (Flores, 2017).

In recent years, the issue of teaching quality and teacher education has attracted the attention of many researchers all over the world (Valeeva \& Gafurov, 2017; Friese, 2016; Maschke \& Stecher, 2016; Woolhouse \& Cochrane, 2015; Brante et al., 2015; Donitsa-Schmidt \& Weinberger, 2014; Childs \& Menter, 2013; Flores, 2011). Linking theory and practice in ITE is of great importance internationally (Valeeva \& Gafurov, 2017; Flores, 2016b; Van Nuland, 2011; Korthagen, Loughran \& Russell, 2006). It is one of the major issues in ITE, but at the same time it is noted in international research that a disconnection exists between theory and practice (Flores, 2016b). Although practicum is recognised as a core element in ITE curricula, there is no consensus about its goals, strategies and required competences (Flores, 2016b). Meanwhile, it is necessary to support classroom practice and research in the curriculum (Valeeva \& Gafurov, 2017).

Several aspects related to ITE are discussed internationally. For example, Tang (2002) points out that student teachers are active agents making evaluative judgments on the more theoretical forms of knowledge learnt 
in higher education. Evans (2010) identified teacher education graduates' strong focus on the classroom and their belief that only experience can truly prepare them for teaching. Wæge and Haugaløkken's (2013) study shows the importance of the direct relevance of theory to daily tasks in the classroom (Tang, Wong \& Cheng, 2016). While these studies show the tendency to privilege practice over theory, in the study developed by Allen and Wright (2014) on a Master's programme in postgraduate teaching, student teachers widely valued both the theoretical and practical components in their programme. Taken together, these studies are important for understanding the subjective experiences of student teachers and assessing the value of different aspects of ITE (Tang, Wong \& Cheng, 2016).

The theory-practice debate is a perennial issue in the field of teacher education (Korthagen, 2010; Kessels \& Korthagen, 1996; Shulman, 1998), and the issue has been analysed in the structural arrangement of ITE programmes. Hennissen, Beckers, and Moerkerke (2017) identify two major approaches of the ITE programme structure regarding the theory-practice relationship: (1) a deductive (theory-first) approach which begins with theory and focuses on how to use theory in practice, and (2) an inductive (practice-first) approach which starts with practical experiences and the need to link them to theory (Tang et al., 2019).

Research that examines student teachers' perspectives suggests that they tend to prioritise practice over the more theoretical aspects of ITE (Mayer et al., 2015; Tang, Wong \& Cheng, 2012; Hobson et al., 2008) and judge the value of theory with respect to direct relevance to daily tasks in the classroom (Tang et al., 2019; Wæge \& Haugaløkken, 2013).

The implementation of research in ITE has been internationally identified as a key element in its development and improvement (Flores, 2016b; Munthe \& Rogne, 2015; Niemi \& Nevgi, 2014; Kansanen 2014). Flores (2016b, p. 212) notes that "in some cases it is non-existent; in other cases it is not explicit in the curriculum but it is up to the training institutions to foster the development of student teachers' research competences, for instance during practicum; and, in other cases, an explicit curriculum unit on research methods is included in the curriculum as well as an inquiry approach to the practicum". Thus, it is essential that student teachers develop deep understandings about teaching and learning by investigating their 
own practice, as learning to be a teacher is a complex, contextual and idiosyncratic process (Flores, 2019b, 2006, 2001).

\section{Teacher Education in Portugal and Poland}

Portugal and Poland are both part of the European Union and thus, despite many cultural differences, there are also similar aspects that led us to consider these two countries in the present study.

Teacher education in Portugal and Poland, especially Initial Teacher Education, is - similarly to other European countries - part of the higher education system (Madalińska-Michalak, 2018). In Poland in 2005 and in Portugal in 2006, the governments approved acts that made changes to the new model of higher education organisation regarding studies and their duration, in accordance with the principles of the Bologna Declaration (in Poland, the Law on Higher Education Act of 27 July 2005; in Portugal, Decree-Law No. 74/2006 of 24 March). In both countries, higher education is organised into a binary system consisting of university education and polytechnic education, each with distinct purposes that translate into specific curricular concepts (Rede Eurydice, 2010). The first cycle of the higher education system - undergraduate level - lasts for three years; the second cycle - Master's degree level - lasts for two years, and the Integrated Master's degree combines the first and second cycles (five years); and the third cycle - Ph.D. - lasts for a maximum of five years. Under the Bologna Process, a number of common tools have been developed to support the transformation process for more student-focused systems. These include the European Credit Transfer and Accumulation System (ECTS), the Diploma Supplement and the National Qualification Frameworks. In the course of the Bologna Process, the ECTS has clearly emerged as a crucial element in a process aimed at making European higher education more transparent and intelligible (Rede Eurydice, 2009; Stachowiak-Kudła, 2012).

The ITE programmes in Portugal have been restructured as a result of the implementation of the Bologna Process. According to the legal framework (Decree-Law No. 43/2007), the professional qualifications for teaching (from pre-school to secondary education) are to be based on a number of key elements: (i) a higher professional qualification for teachers (second-cycle level, i.e. Master's degree); (ii) a curriculum based on learning outcomes in the light of teacher 
performance; (iii) a research-based qualification; (iv) the importance of practicum (observation and collaboration in teaching situations under the supervision of a mentor/supervisor); (v) school-university partnerships; and (vi) the quality assurance of teachers' qualifications and ITE (Flores \& Ferreira, 2016). In 2014, a new legal framework for ITE in Portugal was published (Decree-Law No. 79/2014), which includes the following curriculum components: (i) training in the subject matter; (ii) general educational training; (iii) specific didactics (for a given level of teaching and subject matter); (iv) cultural, social and ethical education; and (v) professional practice (Flores \& Ferreira, 2016).

In Poland, from 1990 up to 2015, ITE was provided within two sectors of the education system: the higher education sector and the school education sector. Degree programmes, including first-, second- and long-cycle programmes, were offered within university type HEls, namely universities, technical universities, polytechnics and academies. Non-degree postgraduate programmes were offered in non-university HEls (with no rights to confer the academic degree of doctor). In the school education sector, college programmes, including teacher training colleges and foreign language teacher training colleges, were offered. From 2015 onwards, ITE has only been offered at higher education institutions.

ITE and training standards were formulated in the Regulations of the Minister of Science and Higher Education on initial teacher training standards $(2012,2019)$. This legislation regulates ITE for school education teachers, thus defining training models or paths that lead to the qualifications required to enter the teaching profession. However, a huge level of autonomy was left to the universities that were responsible for designing the programmes for prospective teachers.

In the current context, the minimum qualification for teaching at pre-primary and primary level (the first stage: grades 1-3) is still a tertiary education degree at bachelor level, which is obtained after three years. However, pursuant to the Regulation of the Minister of Science and Higher Education of 27 September 2018 and the Regulation of the Minister of Science and Higher Education of 25 July 2019 regarding ITE studies, studies in the field of pre-school and early school education are conducted - as they were before 2005 as uniform five-year Master's studies. This has obvious consequences for teacher education in this field. 
For those intending to work at primary schools (the second stage: grades 4-8) and at upper secondary level, the final qualification is a Master's degree. At present, teachers who hold a higher education diploma (a bachelor's or Master's degree) represent $98 \%$ of all teachers working in the school education sector. Master's degree studies seem to be the most popular route of training for teachers in school education of all levels. In Poland, the high quality of pre-school education is guaranteed by the very well-prepared teaching staff at nursery schools. They are mostly university graduates holding a Master's degree (84.0\% of teaching staff) or, less often, a bachelor's degree $(11.8 \%)$ (Madalińska-Michalak, 2017).

Two models of initial training exist side by side: the first is the concurrent model, which is the prevalent one. Students following a degree programme in a given field of study may choose a teacher specialisation track; in this way, they complete their professional teacher training and acquire a teaching qualification, as part of their degree programme, parallel to their subject-specific training. The second is the consecutive model, which is available to those who have not taken a teacher specialisation track as part of a degree programme in a given field of study and choose the teaching profession later. They may obtain a teaching qualification upon the completion of a non-degree postgraduate programme or a qualification course (Kolanowska, 2018).

\section{Method and data collection}

Data were obtained through the administration of a survey to university students in both countries. In Portugal, data were collected between February and June 2017. After obtaining the authorisation to conduct the study from the Presidents of Faculties, Schools and Institutes and from the Presidents of the Pedagogical Council of each Faculty, School and Institute, acceptance was obtained from directors of the programmes. In Poland, data were collected between February and June 2018. After obtaining the authorisation to conduct the study, the questionnaire was translated into Polish and subsequently validated by higher education experts. A face-to-face questionnaire was administered by the researcher in both countries to student teachers attending all years of studies in teacher education programmes of the $1^{\text {st }}$ and $2^{\text {nd }}$ cycles of studies. 


\section{Participants}

In total, 789 student teachers participated: 355 Portuguese students from five public universities and 434 Polish students from four public universities. Missing information relates to the fact that some students did not answer the question. A detailed description of the demographic characteristics of the participants is presented in Table 1.

Table 1. Demographic characteristics of the participants

\begin{tabular}{|c|c|c|c|c|}
\hline \multirow{2}{*}{$\begin{array}{l}\text { DEMOGRAPHIC } \\
\text { CHARACTERISTICS }\end{array}$} & \multicolumn{2}{|c|}{ PORTUGAL } & \multicolumn{2}{|c|}{ POLAND } \\
\hline & $\mathbf{N}$ & $\%$ & $\mathbf{N}$ & $\%$ \\
\hline \multicolumn{5}{|c|}{ GENDER } \\
\hline Male & 57 & 16.1 & 16 & 3.7 \\
\hline Female & 280 & 78.9 & 407 & 93.8 \\
\hline Missing & 18 & 5.0 & 11 & 2.5 \\
\hline \multicolumn{5}{|c|}{ AGE } \\
\hline Under 20 & 97 & 27.3 & 74 & 17.1 \\
\hline [20-25] & 191 & 53.8 & 323 & 74.4 \\
\hline [26-30] & 22 & 6.2 & 18 & 4.1 \\
\hline [31-35] & 17 & 4.8 & 7 & 1.6 \\
\hline [36-40] & 13 & 3.7 & 9 & 2.1 \\
\hline Over 40 & 13 & 3.7 & 1 & 0.2 \\
\hline Missing & 2 & 0.5 & 2 & 0.5 \\
\hline \multicolumn{5}{|c|}{ CYCLE OF STUDY } \\
\hline Undergraduate & 194 & 54.6 & 268 & 61.8 \\
\hline Master's degree & 161 & 45.4 & 166 & 38.2 \\
\hline \multicolumn{5}{|c|}{ YEAR OF STUDY } \\
\hline $1^{\text {st }}$ year & 183 & 51.6 & 262 & 60.4 \\
\hline $2^{\text {nd }}$ year & 109 & 30.7 & 75 & 17.3 \\
\hline $3^{\text {rd }}$ year & 61 & 17.2 & 96 & 22.1 \\
\hline $4^{\text {th }}$ year & - & - & 1 & 0.2 \\
\hline Missing & 2 & 0.5 & - & - \\
\hline Total & 355 & 100.0 & 434 & 100.0 \\
\hline
\end{tabular}




\section{Instruments}

The construction of the scales was based upon previous work (Flores et al., 2019a; Pereira, 2011, 2016). The scale of the ideas associated with assessment included 14 items that comprised positive ideas (e.g. learning, reflection, success, help), negative ideas (e.g. unfairness, anxiety, fear) and neutral ideas (e.g. grades, verification of knowledge, tests). The list of ideas was derived from the literature, namely from the work done by Hadji (1994) and Figari (1996) related to functions of assessment.

The second scale, related to assessment methods, included 14 items comprising learner-centred methods (e.g. project-based work, portfolios, practical work) and traditional methods (e.g. tests/exams, oral tests). The list of methods was derived from the literature, namely Flores et al. (2015), Webber (2012), Struyven, Dochy and Janssens (2005) and Falchikov (2005). A four-point Likert scale was used in both cases, ranging from $1=$ not at all to $4=$ a lot, in order to identify the frequency of the ideas associated with assessment and methods used in both countries.

\section{Data analysis}

Data obtained through the "ideas associated with assessment" scale were subject to a descriptive data analysis using SPSS (Statistical Package for the Social Sciences) software version 26 to understand which ideas are most associated with the assessment.

In Table 2, a list of items considered in the questionnaires is presented. Students used a Likert scale in which $1=$ not at all, $2=$ a little, $3=$ fairly, and $4=\mathrm{a}$ lot to select the answer that best suited their experiences as students in higher education. The number of responses $(n)$ for each of the 14 items and the respective percentages (\%) are also displayed. Data from both countries are presented. 
Table 2. Descriptive analysis of the "ideas associated with assessment" scale

\begin{tabular}{|c|c|c|c|c|c|c|c|c|}
\hline \multirow{3}{*}{ ITEM } & \multicolumn{4}{|c|}{ PORTUGAL } & \multicolumn{4}{|c|}{ POLAND } \\
\hline & \multicolumn{2}{|l|}{$\mathbf{N}$} & \multicolumn{2}{|l|}{$\%$} & \multicolumn{2}{|l|}{$\mathbf{N}$} & \multicolumn{2}{|l|}{$\%$} \\
\hline & $\begin{array}{l}\text { NOT AT ALL } \\
\text { IA LITTLE }\end{array}$ & $\begin{array}{l}\text { FAIRLY } \\
\text { /A LOT }\end{array}$ & $\begin{array}{c}\text { NOT AT ALL } \\
\text { IA LITTLE }\end{array}$ & $\begin{array}{l}\text { FAIRLY } \\
\text { IA LOT }\end{array}$ & $\begin{array}{l}\text { NOT AT ALL } \\
\text { IA LITTLE }\end{array}$ & $\begin{array}{l}\text { FAIRLY } \\
\text { /A LOT }\end{array}$ & $\begin{array}{l}\text { NOT AT ALL } \\
\text { IA LITTLE }\end{array}$ & $\begin{array}{l}\text { FAIRLY } \\
\text { IA LOT }\end{array}$ \\
\hline $\begin{array}{l}\text { 1. Verification } \\
\text { of knowledge }\end{array}$ & 70 & 283 & 19.7 & 79.7 & 76 & 354 & 17.5 & 81.6 \\
\hline 2. Negotiation & 252 & 102 & 71.0 & 28.8 & 339 & 91 & 78.1 & 21.0 \\
\hline 3. Participation & 105 & 241 & 29.6 & 67.9 & 298 & 130 & 68.6 & 29.9 \\
\hline 4. Imposition & 216 & 134 & 60.8 & 37.8 & 147 & 283 & 33.9 & 65.2 \\
\hline 5. Conflict & 278 & 75 & 78.3 & 21.1 & 379 & 53 & 87.3 & 12.2 \\
\hline 6. Success & 68 & 282 & 19.2 & 80.4 & 157 & 274 & 36.2 & 63.1 \\
\hline 7. Grades & 27 & 326 & 7.6 & 91.8 & 114 & 316 & 26.2 & 72.8 \\
\hline 8. Tests/Exams & 56 & 297 & 15.7 & 83.7 & 38 & 395 & 8.8 & 95.7 \\
\hline 9. Reflection & 103 & 249 & 29.0 & 70.2 & 267 & 163 & 61.5 & 37.8 \\
\hline 10. Learning & 57 & 294 & 16.0 & 82.8 & 50 & 380 & 11.5 & 87.5 \\
\hline 11. Unfairness & 221 & 132 & 62.3 & 37.2 & 294 & 138 & 67.7 & 31.8 \\
\hline 12. Help & 154 & 196 & 43.4 & 55.2 & 262 & 168 & 60.3 & 38.7 \\
\hline $\begin{array}{l}\text { 13. Anxiety / } \\
\text { Stress }\end{array}$ & 92 & 259 & 25.9 & 73.0 & 129 & 304 & 29.7 & 70.1 \\
\hline 14. Fear & 139 & 199 & 39.2 & 56 & 193 & 229 & 44.5 & 52.8 \\
\hline
\end{tabular}

Data obtained through the "assessment methods" scale were also subject to a descriptive data analysis using SPSS version 26 to understand which assessment methods are most used by teachers to assess students.

In Table 3, a list of items related to the assessment methods scale is presented. Students used a Likert scale in which $1=$ not at all, $2=\mathrm{a}$ little, $3=$ fairly, and $4=\mathrm{a}$ lot to select the answer that best suited their experiences as students in higher education. The number of responses ( $n$ ) for each of the 14 items and the respective percentages (\%) are also displayed. Data from both countries are presented. 
Table 3. Descriptive analysis of the "assessment methods" scale

\begin{tabular}{|c|c|c|c|c|c|c|c|c|}
\hline \multirow{3}{*}{ ITEM } & \multicolumn{4}{|c|}{ PORTUGAL } & \multicolumn{4}{|c|}{ POLAND } \\
\hline & \multicolumn{2}{|l|}{ N } & \multicolumn{2}{|l|}{$\%$} & \multicolumn{2}{|l|}{ N } & \multicolumn{2}{|l|}{$\%$} \\
\hline & $\begin{array}{l}\text { NOT AT ALL } \\
\text { /A LITTLE }\end{array}$ & $\begin{array}{l}\text { FAIRLY } \\
\text { /A LOT }\end{array}$ & $\begin{array}{l}\text { NOT AT ALL } \\
\text { /A LITTLE }\end{array}$ & $\begin{array}{l}\text { FAIRLY } \\
\text { IA LOT }\end{array}$ & $\begin{array}{l}\text { NOT AT ALL } \\
\text { /A LITTLE }\end{array}$ & $\begin{array}{l}\text { FAIRLY } \\
\text { IA LOT }\end{array}$ & $\begin{array}{l}\text { NOT AT ALL } \\
\text { /A LITTLE }\end{array}$ & $\begin{array}{l}\text { FAIRLY } \\
\text { /A LOT }\end{array}$ \\
\hline $\begin{array}{l}\text { 1. Written Tests / } \\
\text { Exams }\end{array}$ & 82 & 271 & 23.1 & 76.4 & 44 & 389 & 10.1 & 89.9 \\
\hline $\begin{array}{l}\text { 2. Oral Tests / } \\
\text { Exams }\end{array}$ & 238 & 109 & 67.0 & 30.7 & 339 & 94 & 78.1 & 21.6 \\
\hline $\begin{array}{l}\text { 3. Collective } \\
\text { Portfolios }\end{array}$ & 248 & 103 & 69.8 & 29.0 & 352 & 63 & 81.1 & 14.5 \\
\hline $\begin{array}{l}\text { 4. Individual } \\
\text { Portfolios }\end{array}$ & 225 & 126 & 63.3 & 35.5 & 365 & 67 & 84.1 & 15.5 \\
\hline $\begin{array}{l}\text { 5. Individual } \\
\text { practical } \\
\text { or experimental } \\
\text { work }\end{array}$ & 132 & 147 & 37.2 & 41.4 & 373 & 56 & 86.0 & 12.9 \\
\hline $\begin{array}{l}\text { 6. Practical } \\
\text { or experimental } \\
\text { group work }\end{array}$ & 54 & 296 & 15.2 & 83.3 & 312 & 120 & 71.9 & 27.7 \\
\hline $\begin{array}{l}\text { 7. Individual } \\
\text { projects }\end{array}$ & 212 & 138 & 59.7 & 38.9 & 285 & 147 & 65.6 & 33.8 \\
\hline 8. Group projects & 108 & 244 & 30.4 & 68.8 & 150 & 283 & 34.6 & 65.2 \\
\hline $\begin{array}{l}\text { 9. Individual } \\
\text { reports }\end{array}$ & 143 & 207 & 40.3 & 58.3 & 353 & 76 & 81.4 & 17.5 \\
\hline 10. Group reports & 112 & 240 & 31.5 & 67.7 & 357 & 73 & 82.2 & 16.8 \\
\hline $\begin{array}{l}\text { 11. Individual } \\
\text { written } \\
\text { reflections }\end{array}$ & 142 & 210 & 40.0 & 59.1 & 244 & 188 & 56.3 & 43.3 \\
\hline $\begin{array}{l}\text { 12. Reflections } \\
\text { written } \\
\text { in a group }\end{array}$ & 163 & 124 & 45.9 & 34.9 & 299 & 95 & 68.9 & 21.9 \\
\hline $\begin{array}{l}\text { 13. Individual oral } \\
\text { presentations }\end{array}$ & 206 & 88 & 58.1 & 24.8 & 283 & 149 & 65.2 & 34.4 \\
\hline $\begin{array}{l}\text { 14. Group oral } \\
\text { presentations }\end{array}$ & 47 & 298 & 13.5 & 83.9 & 174 & 256 & 40.1 & 59.0 \\
\hline
\end{tabular}

Data from the ideas associated with assessment scale were subject to an exploratory factor analysis (EFA) and a confirmatory factor analysis (CFA), resulting in a 3-factor model, in which the factors were as follows: (1) formative purpose of assessment; (2) summative purpose of assessment; and (3) negative emotions associated with the assessment. Table 4 shows that an EFA was performed using the data of the calibration sample in order to explore the factors underlying the data. These models used 
an oblique geomin rotation, and a minimum loading of .30 was required for practical significance. The resulting structure was then tested in the cross-validation sample using a CFA. The model's modification was performed based on modification indices with reference to standardised expected parameter changes. Composite reliability was also assessed by computing McDonald's omega coefficient $(\omega)$. Values higher than .70 were considered adequate (Hair et al., 2009).

Table 4. Factors of the "ideas associated with assessment" scale

\begin{tabular}{l|l|c|c|c|c|c|c}
\multicolumn{1}{c|}{ FACTOR } & \multicolumn{1}{c|}{ ITEMS } & \multicolumn{2}{c|}{ PORTUGAL } & \multicolumn{3}{c}{ POLAND } \\
\hline & & N & M & SD & N & M & SD \\
\hline $\begin{array}{l}\text { Formative purpose } \\
\text { of the assessment } \\
\text { 6. Success } \\
\text { 9. Reflection } \\
\text { 10. Learning } \\
\text { 12. Help }\end{array}$ & 337 & 2.83 & 0.47 & 420 & 2.53 & 0.49 \\
\hline $\begin{array}{l}\text { Summative purpose } \\
\text { of the assessment }\end{array}$ & $\begin{array}{l}\text { 1. Verification } \\
\text { of knowledge } \\
\text { 7. Grades } \\
\text { 8. Tests / Exams }\end{array}$ & 351 & 3.14 & 0.51 & 427 & 3.20 & 0.52 \\
\hline $\begin{array}{l}\text { Negative emotions } \\
\text { associated with } \\
\text { the assessment }\end{array}$ & $\begin{array}{l}\text { 13. Anxiety / Stress } \\
\text { 14. Fear }\end{array}$ & 337 & 2.91 & 0.85 & 422 & 2.86 & 0.92 \\
\hline
\end{tabular}

$M=$ mean; $S D=$ standard deviation.

Data obtained through the assessment methods scale were subject to an EFA and a CFA, resulting in a 3-factor model: (1) collective assessment methods, (2) individual assessment methods, and (3) portfolios. Table 5 shows that an EFA was performed using the data of the calibration sample in order to explore the factors underlying the data. These models used an oblique geomin rotation, and a minimum loading of .30 was required for practical significance. The resulting structure was then tested in the cross-validation sample using a CFA. The model's modification was performed based on modification indices with reference to standardised expected parameter changes. Composite reliability was also assessed by computing McDonald's omega coefficient $(\omega)$. Values higher than .70 were considered adequate (Hair et al., 2009). 
Table 5. Factors of the "assessment methods" scale

\begin{tabular}{|c|c|c|c|c|c|c|c|}
\hline \multirow[t]{2}{*}{ FACTOR } & \multirow[t]{2}{*}{ ITEMS } & \multicolumn{3}{|c|}{ PORTUGAL } & \multicolumn{3}{|c|}{ POLAND } \\
\hline & & $n$ & $M$ & $S D$ & $n$ & $M$ & $S D$ \\
\hline $\begin{array}{l}\text { Collective methods } \\
\text { of assessment }\end{array}$ & $\begin{array}{l}\text { 6. Practical } \\
\text { or experimental } \\
\text { group work } \\
\text { 8. Group projects } \\
\text { 10. Group reports } \\
\text { 14. Group oral } \\
\text { presentations }\end{array}$ & 342 & 3.00 & 0.59 & 425 & 2.30 & 0.92 \\
\hline $\begin{array}{l}\text { Individual methods } \\
\text { of assessment }\end{array}$ & $\begin{array}{l}\text { 7. Individual projects } \\
\text { 9. Individual reports } \\
\text { 11. Individual } \\
\text { written reflections } \\
\text { 13. Individual oral } \\
\text { presentations }\end{array}$ & 343 & 2.47 & 0.73 & 427 & 2.62 & 0.64 \\
\hline \multirow[t]{2}{*}{ Portfolios } & $\begin{array}{l}\text { 3. Collective portfolios } \\
\text { 4. Individual portfolios }\end{array}$ & 349 & 2.11 & 0.85 & 432 & 1.72 & 0.48 \\
\hline & Total & 355 & & & 434 & & \\
\hline
\end{tabular}

$M=$ mean $; S D=$ standard deviation.

As for the "ideas associated with assessment" scale, the analysis of the data of the Portuguese participants revealed that they associate assessment with more positive ideas such as participation, success, reflection, learning and help and neutral ideas such as verification of knowledge, grades and tests. The ideas less associated with assessment were negotiation, imposition, conflict and unfairness. As for Polish students, they associate assessment with ideas such as verification of knowledge, grades and tests (neutral ideas), success and learning (positive ideas) and anxiety and fear (negative ideas). The ideas less associated with assessment were negotiation, participation, conflict, reflection, unfairness and help.

These results reveal that Portuguese and Polish students do not have a similar understanding of the ideas most associated with assessment, since the Portuguese students associated more positive ideas with it and the Polish students identified more neutral ideas. In a general comparative perspective (Table 2), negotiation is the idea least associated with assessment by both student groups. As for the idea most associated with assessment, in the case of Portuguese students 
it is grades $(n=326 ; f=91.8 \%)$, while for Polish students it is tests/exams $(n=395 ; f=95.7 \%)$.

With regard to assessment methods, Portuguese students identified written tests/exams, individual practical or experimental work, practical or experimental group work, group projects, individual reports, group reports, individual written reflections, and group oral presentations as the most used methods. As for Polish students, the results show that the most used methods are written tests/exams, group projects and group oral presentations. From a general comparative perspective (Table 3), it is possible to state that both groups of students consider tests/exams the method most used by teachers. The least used methods were, in Portugal, collective portfolios $(n=248 ; f=69.8 \%)$ and, in Poland, individual practical or experimental work $(n=373 ; f=86.0 \%)$. In contrast, the methods most used by teachers were, in Portugal, group oral presentations $(n=298 ; f=83.9 \%)$ and, in Poland, written tests/exams $(n=389 ; f=89.9 \%)$.

In general, students in both countries associate the summative purpose with assessment (grades, tests/exams and verification of knowledge) more than the formative purpose (reflection, learning, participation, help and success) (see Table 4). These data are consistent with results found in other studies that suggest that university students perceive assessment as summative and with little involvement on the part of the students (Flores, 2019b; Barreira et al., 2017; Fernandes, 2015). Educational contexts are mainly oriented towards the classification and hierarchisation of student results. The ideas associated with the summative purpose of assessment are mainly related to the frequent use of written tests/exams.

The analysis of the assessment methods scale shows that Portuguese students are also assessed through collective and portfolio methods, while Polish students are assessed mostly by written tests/exams, group projects and group oral presentations, with limited use of portfolios (see Table 5). As the participants in this study are student teachers, it is important to know which ideas are most associated with assessment and which assessment methods are most used, as these students will be teachers and will need to assess their students. Hence, it is essential for students to have a positive perception of assessment and the different methods that can be used in order to enhance the performance of their future students. Through this 
analysis, it is possible to say that Portuguese students are assessed through a greater variety of individual and group methods, while Polish students are assessed using a smaller range of methods.

\section{Conclusions and implications}

In the context of higher education, assessment takes place mainly on a summative dimension along with the certification of student learning (Flores et al., 2019b; Mimirinis, 2019; Vergés Bausili, 2018; Liu \& Carless, 2006), but ideally it also presupposes formative assessment and the improvement of the teaching and learning process (Gulikers et al., 2008; Boud \& Falchikov, 2007; Biggs, 2003; Brown, Bull \& Pendlebury, 1997; Brown \& Knight, 1994). Therefore, teachers need to be aware that they should use a variety of assessment tasks, the two most common types being formative (designed primarily to improve learning) and summative (designed primarily to judge learning) (Crisp, 2012). There has been a consistency in the evidence presented in the higher education learning and teaching literature over the past decade that indicates that student learning outcomes may be significantly improved through the provision of formative assessments that are coupled with timely feedback (Crisp, 2012; Gibbs, 2006; Nicol \& Macfarlane-Dick, 2006). Although summative assessments may still dominate the attention of many students because of their often high stakes consequences, higher education institutions are incorporating the requirement for formative assessment opportunities in their assessment policies (Crisp, 2012; Chalmers, 2007). In general, research on assessment in higher education reveals, on the one hand, that tests are the most used assessment methods (Flores et al., 2019b, 2015; Pereira, Niklasson \& Flores, 2017) and, on the other, that assessment is seen by students as more effective and fairer when it is carried out using student-centred assessment methods or mixed methods, which include traditional and alternative methods (Pereira, Flores \& Barros, 2017; Flores et al., 2015).

The ideas most associated with assessment are, in general, related to four main aspects: assessment itself, learning, positive ideas and negative ideas (Pereira, Niklasson \& Flores, 2017). The negative feelings reported were anxiety, stress and fear. Earlier studies (Craddock \& Mathias, 2009; Race, 1995) have indicated that these negative feelings influence and reduce the academic performance 
of students. Thus, students' perceptions of assessment will affect their involvement in the learning process (Biggs, 2003).

Our study proves to be pertinent and timely because we are in a time where assessment is at the heart of higher education institutions, whether related to the assessment of students, teachers or even the institutions themselves, in the search for better quality. As such, better results provide greater visibility, attracting more students and more economic power (Koscielniak, 2014; Heck, Johnsrud \& Rosser, 2000). The current emphasis on assessment also implies that evidence of student learning is used as crucial evidence for the quality of programmes in higher education. The growing importance of such evidence appears to be a trend around the world (Praslova, 2010). In addition, this study is innovative, since, to our knowledge, no comparative studies have been carried out in order to understand the ideas that Portuguese and Polish student teachers associate with assessment and the most used assessment methods. Anyone is able to talk about what it is, generically, to assess. But it is important to understand it from the students' own experiences. Our participants are student teachers, contrary to other future professionals, as these students already know the context in which they will exercise their activity: schools and classrooms. Long-term contact with their future profession, through the observations of their teachers, will affect, to a greater or lesser extent, their understanding and teaching practices, both as teacher candidates and as new teachers (Flores, 2010). Thus, it is essential that student teachers develop deep understandings about teaching and learning, including assessment, by investigating their own practices (Flores, 2019b).

\section{References}

$\rightarrow$ Allal, L. (2019). Assessment and the co-regulation of learning in the classroom, Assessment in Education: Principles, Policy \& Practice, 1-18, DOI: 10.1080/0969594X.2019.1609411

$\rightarrow$ Allen, J. and Wright, S. (2014). Integrating theory and practice in the pre-service teacher education practicum, Teachers and Teaching, 20, 136-151.

$\rightarrow$ Baird, J.A., Andrich, D., Hopfenbeck and T., Stobart, G. (2017). Assessment and learning: fields apart?, Assessment in Education: Principles, Policy \& Practice, 24(3), 317-350. 
$\rightarrow$ Barreira, C., Bidarra, G., Monteiro, F., Vaz-Rebelo, P. and Alferes, V. (2017). Avaliação das aprendizagens no ensino superior. Perceções de professores e estudantes nas universidades portuguesas, Revista Iberoamericana de Educación Superior, 8(21), 24-36.

$\rightarrow$ Biggs, J. (2003). Teaching for quality learning at university. Buckingham: Open University Press.

$\rightarrow$ Black, P. and Wiliam, D. (1998). Assessment and Classroom Learning, Assessment in Education: Principles, Policy \& Practice, 5(1), 7-74.

$\rightarrow$ Bloxham, S. and Boyd, P. (2007). Developing effective assessment in higher education: A practical guide. Milton Keynes: Open University Press.

$\rightarrow$ Boud, D. (1990). Assessment and promotion of academic values, Studies in Higher Education, 15(1), 101-113.

$\rightarrow$ Boud, D. (2000), Sustainable Assessment: Rethinking assessment for the learning society, Studies in Continuing Education, 22(2), 151-167.

$\rightarrow$ Boud, D. and Falchikov, N. (2005). Redesigning assessment for learning beyond higher education, Higher Education, 28, 34-41

$\rightarrow$ Boud, D. and Falchikov, N. (2006). Aligning Assessment with Long Term Learning, Assessment and Evaluation in Higher Education, 31(4), 399-413.

$\rightarrow$ Boud, D. and Falchikov, N. (2007). Rethinking assessment in higher education: learning for the long term. New York: Routledge.

$\rightarrow$ Bourner, T. (2003). Assessing reflective learning, Education and Training, 45(4/5), 267-272.

$\rightarrow$ Brante, G., Olander, M., Holmquist, P. and Palla, M. (2015). Theorising Teaching and Learning: Preservice Teachers' Theoretical Awareness of Learning, European Journal of Teacher Education, 38(1), 102-118.

$\rightarrow$ Broadfoot, P. and Black, P. (2004). Redefining Assessment? the First Ten Years of Assessment in Education, Assessment in Education: Principles, Policy \& Practice, 11(1), 7-26.

$\rightarrow$ Brown, N.A., Dewey, D.P. and Cox, T.L. (2014). Assessing the Validity of Can-Do Statements in Retrospective (Then-Now) Self-Assessment, Foreign Language Annals, 47(2), 261-285.

$\rightarrow$ Brown, G., Bull, J. and Pendlebury, M. (1997). Assessing student learning in higher education. London: Routledge.

$\rightarrow$ Brown, H.D. (2004). Language Assessment: Principles and Classroom Practice. New York: Longman.

$\rightarrow$ Brown, S. (2005), Assessment for Learning, Learning and Teaching in Higher Education, 1, 81-89. 
$\rightarrow$ Brown, S. and Glasner, A. (1999). Assessment Matters in Higher Education. Buckingham: Open University Press.

$\rightarrow$ Brown, S. and Knight, P. (1994). Assessing Learners in Higher Education. London: Kogan Page.

$\rightarrow$ Byrne, M., Finlayson, O., Flood, B., Lyons, O. and Willis, P. (2010). A Comparison of the learning approaches of accounting and science students at an Irish university, Journal of Further and Higher Education, 34(3), 369-383.

$\rightarrow$ Byrne, M. and Flood, B. (2005). A study of accounting students' motives, expectations and preparedness for higher education, Journal of Further and Higher Education, 29(2), 111-124.

$\rightarrow$ Carless, D. (2007). Learning-oriented assessment: conceptual bases and practical implications, Innovations in Education and Teaching International, 44(1), 57-66.

$\rightarrow$ Carless, D. (2011). From Testing to Productive Student Learning: Implementing Formative Assessment in Confucian-Heritage Settings. New York: Routledge.

$\rightarrow$ Chalmers, D. (2007). A review of Australian and international quality systems and indicators of learning and teaching, ALTC Project Report. www.altc.edu. au/resource-reviewindicators- teaching-learning

$\rightarrow$ Childs, A. and Menter, I. (2013). Teacher Education in the $21^{\text {st }}$ Century in England: A Case Study in Neo-Liberal Policy, Revista Espanola de Educacion Camparada, 22, 93-116.

$\rightarrow$ Craddock, D. and Mathias, H. (2009). Assessment options in higher education, Assessment \& Evaluation in Higher Education, 34(2), 127-140.

$\rightarrow$ Crisp, G. (2012). Integrative assessment: reframing assessment practice for current and future learning, Assessment \& Evaluation in Higher Education, 37(1), 33-43.

$\rightarrow$ Darling-Hammond, L. (2012). Teacher Preparation and Development in the United States: A Changing Policy Landscape. In: L. Darling-Hammond, A. Lieberman (eds.), Teacher Education around the World. Changing Policies and Practices (pp. 130-150). London: Routledge.

$\rightarrow$ Darling-Hammond, L., Newton, X. and Wei, R.C. (2010). Evaluating teacher education outcomes: A study of the Stanford Teacher Education Programme, Journal of Education for Teaching, 36, 369-388.

$\rightarrow$ Dochy, F., Segers, M. and Sluijsmans, D. (1999). The Use of Self-, Peer-, and Co-assessment in Higher Education: A Review, Studies in Higher Education, 24(3), 331-350.

$\rightarrow$ Donald, S. (2010). International perspectives on research in initial teacher education and some emerging issues, Journal of Education for Teaching, 36(4), 345-351. 
$\rightarrow$ Donitsa-Schmidt, S. and Weinberger, Y. (2014). Do Alternative Teacher Education Programs Manage to Attract Different Candidates and Students? Teacher Development, 18(4), 530-545.

$\rightarrow$ Eurydice/European Commission/EACEA (2018). Teaching Careers in Europe: Access, Progression and Support. Eurydice Report. Luxembourg: Publications Office of the European Union.

$\rightarrow$ Evans, L. (2010). Professionals or technicians? Teacher preparation programs and occupational understandings, Teachers and Teaching, 16, 183-205.

$\rightarrow$ Falchikov, N. (2005). Improving assessment through student involvement: practical solutions for aiding learning in higher and further education. London: Routledge Falmer.

$\rightarrow$ Falchikov, N. (2007). The Place of Peers in Learning and Assessment. In: D. Boud, N. Falchikov (eds.), Rethinking Assessment in Higher Education: Learning for the Longer Term (pp. 128-143). New York: Routledge.

$\rightarrow$ Fernandes, D. (2015). Pesquisa de percepções e práticas de avaliação no ensino universitário português, Estudos em Avaliação Educacional, 26(63), 596-629.

$\rightarrow$ Flores, M.A. (2001). Person and Context in Becoming a New Teacher, Journal of Education for Teaching, 27(2), 135-148.

$\rightarrow$ Flores, M.A. (2006). Being a Novice Teacher in Two Different Settings: Struggles, Continuities, and Discontinuities, Teachers College Record, 108(10), 2021-2052.

$\rightarrow$ Flores, M.A. (2010). Algumas reflexões em torno da formação inicial de professores, Educação, 33(3), 182-188.

$\rightarrow$ Flores, M.A. (2011). Curriculum of initial teacher education in Portugal: New contexts, old problems, Journal of Education for Teaching, 37, 461-470.

$\rightarrow$ Flores, M.A. (2016a). Contexts of teaching and professional learning, Teachers and Teaching, 22(2), 127-130.

$\rightarrow$ Flores, M.A. (2016b). Teacher Education Curriculum. In: J. Loughran, M.L. Hamilton (eds.), International Handbook of Teacher Education (pp. 187-230). Dordrecht: Springer.

$\rightarrow$ Flores, M.A. (2017). Practice, theory and research in initial teacher education: international perspectives, European Journal of Teacher Education, 40(3), 287-290.

$\rightarrow$ Flores, M.A. (2019a). Learning to be a teacher: mentoring, collaboration and professional practice, European Journal of Teacher Education, 42(5), 535-538.

$\rightarrow$ Flores, M.A. (2019b). Introdução. In: M.A. Flores, Avaliação no Ensino Superior: Conceções e Práticas (pp. 15-21). Santo Tirso: De Facto Editores. 
$\rightarrow$ Flores, M.A. (2020). Feeling like a student but thinking like a teacher: a study of the development of professional identity in initial teacher education, Journal of Education for Teaching, 46(2), 145-158.

$\rightarrow$ Flores, M.A. and Ferreira, F.I. (2016). Education and child poverty in times of austerity in Portugal: implications for teachers and teacher education, Journal of Education for Teaching, 42(4), 404-416.

$\rightarrow$ Flores, M.A., Pereira, D., Fernandes, E., Santos, P., Pinheiro, C. and Coutinho, C. (2019a). O projeto de investigação. In: M.A. Flores, Avaliação no Ensino Superior: Conceções e Práticas (pp. 49-74). Santo Tirso: De Facto Editores.

$\rightarrow$ Flores, M.A., Pereira, D., Fernandes, E. and Coutinho, C. (2019b), Conclusões e Implicações. In: M.A. Flores, Avaliação no Ensino Superior: Conceções e Práticas (pp. 229-254). Santo Tirso: De Facto Editores.

$\rightarrow$ Flores, M., Veiga Simão, M., Barros, A. and Pereira, D. (2015). Perceptions of effectiveness, fairness and feedback of assessment methods: a study in higher education, Studies in Higher Education, 40(9), 1523-1534.

$\rightarrow$ Flores, M.A., Vieira, F., Silva, J.L. and Almeida, J. (2016). Integrating Research into the Practicum: Inquiring into Inquiry based Professional Development in Post-Bologna Initial Teacher Education in Portugal. In: M.A. Flores, T. Al-Barwani (eds.), Redefining Teacher Education for the post-2015 Era: Global Challenges and Best Practice (pp. 109-124). New York: Nova Science.

$\rightarrow$ Figari, G. (1996). Avaliar: que referencial?. Porto: Porto Editora.

$\rightarrow$ Filipkowski, A. (2003). The implementation of the Bologna Declaration in Poland, European Journal of Engineering Education, 28(2), 237-245.

$\rightarrow$ Freeman, M. (1995). Peer Assessment by Groups of Group Work, Assessment \& Evaluation in Higher Education, 20(3), 289-300.

$\rightarrow$ Friese, M. (2016). Vocational Teacher Training in Germany, Obrazovanie i samorazvitie - Education and Self-Development, 11(3), 28-35.

$\rightarrow$ Gibbs, G. (1999). Using Assessment Strategically to Change the Way Students Learn. In: S. Brown, A. Glasner, Assessment Matters in Higher Education: Choosing and Using Diverse Approaches (pp. 41-53). Buckingham: Open University Press.

$\rightarrow$ Gibbs, G. (2006). Why assessment is changing. In: C. Bryan, K. Clegg, Innovative assessment in higher education (pp. 11-22). London: Routledge.

$\rightarrow$ Gibbs, G. and Rowntree, D. (1999). Teaching in Higher Education: Theory and Evidence. Milton Keynes: Open University Press.

$\rightarrow$ Goodwin, A. (2012). Quality Teachers, Singapore Style. In: L. Darling-Hammond, A. Lieberman (eds.), Teacher Education Around the World: Changing Policies and Practices (pp. 22-43). London: Routledge. 
$\rightarrow$ Gulikers, J., Kester, L., Kirschner, P. and Bastiaens, T. (2008). The effect of practical experience on perceptions of assessment authenticity, study approach, and learning outcomes, Learning and Instruction, 18, 172-186.

$\rightarrow$ Hadji, C. (1994). A Avaliação, Regras do Jogo. Das Intenções aos Instrumentos. Porto: Porto Editora.

$\rightarrow$ Hammerness, K., Tartwijk, J. van, Snoek, M. (2012). Teacher Preparation in the Netherlands: Shared Visions and Common Features. In: L. Darling-Hammond, A. Lieberman (eds.), Teacher Education around the World. Changing Policies and Practices (pp. 44-65). London: Routledge.

$\rightarrow$ Hair, J.F., Black, W.C., Babin, B.J. and Anderson, R.E. (2009). Multivariate data analysis ( $7^{\text {th }}$ ed.). Upper Saddle River: Prentice Hall.

$\rightarrow$ Hassan, O., Fox, A. and Hannah, G. (2014). Self- and peer-assessment: Evidence from the accounting and finance discipline, Accounting Education, 23(3), 225-243.

$\rightarrow$ Heck, R., Johnsrud, L. and Rosser, V. (2000). Administrative, Effectiveness in Higher Education: Improving Assessment Procedures, Research in Higher Education, 41(6), 663-684.

$\rightarrow$ Hennissen, P., Beckers, H. and Moerkerke, G. (2017). Linking Practice to Theory in Teacher Education: A Growth in Cognitive Structures, Teaching and Teacher Education, 63, 314-325.

$\rightarrow$ Hernández, R. (2012). Does continuous assessment in higher education support student learning?, Higher Education, 64, 489-502.

$\rightarrow$ Heywood, J. (2000). Assessment in higher education. London: Jessica Kingsley.

$\rightarrow$ Hill, T. (2016). Do accounting students believe in self-assessment?, Accounting Education, 25(4), 291-305.

$\rightarrow$ Hobson, A. J., Malderez, A., Tracey, L., Giannakaki, M., Pell, G. and Tomlinson, P. (2008). Student Teachers' Experiences of Initial Teacher Preparation in England: Core Themes and Variation, Research Papers in Education, 23(4), 407-433.

$\rightarrow$ Huba, M.E. and Freed, J. (2000). Learner-centered Assessment on College Campuses: Shifting the Focus from Teaching to Learning. Boston: Allyn and Bacon.

$\rightarrow$ Hughes, G. (2011). Towards a personal best: a case for introducing ipsative assessment in higher education, Studies in Higher Education, 36(3), 353-367.

$\rightarrow$ Imig, D., Wiseman, D. and Imig, S. (2011). Teacher Education in the United States of America, Journal of Education for Teaching, 37(4), 399-408.

$\rightarrow$ Jones, N. and Saville, N. (2016). Learning Oriented Assessment: A Systemic Approach (Studies in Language Testing 45). Cambridge: Cambridge University Press. 
$\rightarrow$ Kahl, D. and Venette, S. (2010). To Lecture or Let Go: A Comparative Analysis of Student Speech Outlines from Teacher-Centered and Learner-Centered Classrooms, Communication Teacher, 24(3), 178-186.

$\rightarrow$ Kansanen, P. (2014). Teaching as a Master's Level Profession in Finland: Theoretical Reflections and Practical Solutions. In: O. McNamara, J. Murray, M. Jones (eds.), Workplace Learning in Teacher Education. International Practice and Policy (pp. 279-292). Dordrecht: Springer.

$\rightarrow$ Kessels, J. and Korthagen, F. (1996). The Relationship between Theory and Practice: Back to Classics, Educational Researcher, 25(3), 17-22.

$\rightarrow$ Koscielniak, C. (2014). A consideration of the changing focus on the sustainable development in higher education in Poland, Journal of Cleaner Production, 62, 114-119.

$\rightarrow$ Korthagen, F. (2010). The Relationship between Theory and Practice in Teacher Education. In: P. Peterson, E. Baker, B. McGaw (eds.), International Encyclopaedia of Education (pp. 669-675). London: Elsevier.

$\rightarrow$ Korthagen, F., Loughran and J., Russell, T. (2006). Developing Fundamental Principles for Teacher Education Programs and Practices, Teaching and Teacher Education, 22, 1020-1041.

$\rightarrow$ Light, G. and Cox, R. (2003). Learning and Teaching in Higher Education: The Reflective Professional. London: Sage Publications.

$\rightarrow$ Liu, N. and Carless, D. (2006). Peer feedback: the learning element of peer assessment, Teaching in Higher Education, 11(3), 279-290.

$\rightarrow \mathrm{Li}, \mathrm{X}$. (2018). Self-assessment as "assessment as learning" in translator and interpreter education: validity and washback, The Interpreter and Translator Trainer, 12(1), 48-67.

$\rightarrow$ Li, L. and Gao, F. (2016). The effect of peer assessment on project performance of students at different learning levels, Assessment \& Evaluation in Higher Education, 41(6), 885-900.

$\rightarrow$ Li, L., Liu, X. and Steckelberg, A.L. (2010). Assessor or Assessee: How Student Learning Improves by Giving and Receiving Peer Feedback, British Journal of Educational Technology, 41(3), 525-536.

$\rightarrow$ Li, L., Liu, X. and Zhou, Y. (2012). Give and Take: A Re-analysis of Assessor and Assessee's Roles in Technology-facilitated Peer Assessment, British Journal of Educational Technology, 43(3), 376-384.

$\rightarrow$ Maclellan, E. (2004). How convincing is alternative assessment for use in higher education?, Assessment \& Evaluation in Higher Education, 29(3), 311-321.

$\rightarrow$ Madalińska-Michalak, J. (2017). Teacher education in Poland: Towards teachers' career-long professional learning. In: B. Hudson, Overcoming the fragmentation 
in teacher education policy and practice (pp. 73-100). Cambridge: Cambridge University Press.

$\rightarrow$ Madalińska-Michalak, J. (2018). Teacher Education and the Profile of European Teachers. In: A.R. Simões, M. Lourenço, N. Costa (eds.), Teacher Education Policy and Practice in Europe: Challenges and Opportunities for the Future (pp. 73-100). New York: Routledge.

$\rightarrow$ Malan, M. (2014). Exploring the perceptions of academic trainees on IFRS learning through a new teaching and learning strategy. University of Johannesburg: Johannesburg.

$\rightarrow$ Malan, M. and Stegmann, N. (2018). Accounting students' experiences of peer assessment: A tool to develop lifelong learning, South African Journal of Accounting Research, 32(2-3), 205-224.

$\rightarrow$ Maschke, S. and Stecher, L. (2016). Why Become a Teacher? Considerations on the Initial Study Phase in Teacher Training, Obrazovanie i samorazvitie - Education and Self-Development, 11(3), 36-44.

$\rightarrow$ Mayer, D., Allard, A., Bates, R., Dixon, M., Doecke, B., Kline, J. and Kostogriz, A. (2015). Studying the Effectiveness of Teacher Education: Final Report. Melbourne: Deakin University.

$\rightarrow$ Mayer, D., Pecheone, R. and Merino, N. (2012). Rethinking Teacher Education in Australia: The Teacher Quality Reforms. In: L. Darling-Hammond, A. Lieberman, Teacher Education around the World: Changing Policies and Practices (pp. 110-129). London: Routledge.

$\rightarrow$ Mimirinis, M. (2019). Qualitative differences in academics' conceptions of e-assessment. Assessment \& Evaluation in Higher Education, 44(2), 233-248. DOI: 10.1080/02602938.2018.1493087

$\rightarrow$ Munthe, E. and Rogne, M. (2015). Research Based Teacher Education, Teaching and Teacher Education, 46, 17-24.

$\rightarrow$ Myers, C. and Myers, S. (2015). The use of learner-centered assessment practices in the United States: the influence of individual and institutional contexts, Studies in Higher Education, 40(10), 1904-1918.

$\rightarrow$ Miller, A., Imrie, B. and Cox, K. (1998). Student Assessment in Higher Education: a handbook for assessing performance. London: Kogan Page.

$\rightarrow$ Nicol, D. and Macfarlane-Dick, D. (2006). Formative assessment and self-regulated learning: A model and seven principles of good feedback practice, Studies in Higher Education, 31(2), 199-218.

$\rightarrow$ Nickel, J. and Zimmer, J. (2019). Professional Identity in Graduating Teacher Candidates, Teaching Education, 30(2), 145-159. 
$\rightarrow$ Niemi, H. and Nevgi, A. (2014). Research Studies and Active Learning Promoting Professional Competences in Finnish Teacher Education, Teaching and Teacher Education, 43, 131-142.

$\rightarrow$ Panadero, E., Jonsson, A. and Botella, J. (2017). Effects of self-assessment on self-regulated learning and self-efficacy: Four meta-analyses, Educational Research Review, 22, 74-98.

$\rightarrow$ Panadero, E., Jonsson, A. and Strijbos, J.W. (2016). Scaffolding self-regulated learning through self-assessment and peer assessment: Guidelines for classroom implementation. In: D. Laveault, L. Allal (eds.), Assessment for learning: Meeting the challenge of implementation (pp. 311-326). Cham: Springer.

$\rightarrow$ Patchan, M., Schunn, C., Clark, R. (2018). Accountability in peer assessment: examining the effects of reviewing grades on peer ratings and peer feedback, Studies in Higher Education, 43(12), 2263-2278.

$\rightarrow$ Patri, M. (2002). The Influence of Peer Feedback on Self- and Peer-assessment of Oral Skills, Language Testing, 19(2), 109-131.

$\rightarrow$ Perrenoud, P. (1999). Avaliação, Da excelência à regulação das aprendizagens: entre duas lógicas. Porto Alegre: Artmed.

$\rightarrow$ Pereira, D. and Flores, M.A. (2019). Revisão da Literatura. In: M.A. Flores, Avaliação no Ensino Superior: Conceções e Práticas (pp. 23-48). Santo Tirso: De Facto Editores.

$\rightarrow$ Pereira, D., Niklasson, L. and Flores, M.A. (2017). Students' perceptions of assessment: a comparative analysis between Portugal and Sweden, Higher Education, 73(1), 153-173.

$\rightarrow$ Pereira, D., Flores, M. and Barros, A. (2017). Perceptions of Portuguese undergraduate students about assessment: A study in five public universities, Educational Studies, 43, 442-463.

$\rightarrow$ Pereira, D., Flores, M., Veiga Simão, A. and Barros, A. (2016). Effectiveness and relevance of feedback in Higher Education: A study of undergraduate students, Studies in Educational Evaluation, 49, 7-14.

$\rightarrow$ Pereira, D. (2011). A avaliação das aprendizagens no ensino superior na perspetiva dos estudantes: um estudo exploratório. Braga: Universidade do Minho.

$\rightarrow$ Pereira, D. (2016). Assessment in Higher Education and Quality of Learning: Perceptions, Practices and Implications. Braga: Universidade do Minho.

$\rightarrow$ Peterson, E. and Irving, E. (2008). Secondary school students' conceptions of assessment and feedback, Learning and Instruction, 18, 238-250. 
$\rightarrow$ Pope, N. (2001). An Examination of the Use of Peer Rating for Formative Assessment in the Context of the Theory of Consumption Values, Assessment \& Evaluation in Higher Education, 26(3), 235-246.

$\rightarrow$ Praslova, L. (2010). Adaptation of Kirkpatrick's four level model of training criteria to assessment of learning outcomes and program evaluation in Higher Education, Educational Assessment, Evaluation and Accountability, 22, 215-225.

$\rightarrow$ Race, P. (1995). What has assessment done for us - And to us?. In: P. Knight, Assessment for learning in higher education (pp. 61-74). London: Kogan Page.

$\rightarrow$ Ramon-Casas, M., Nuño, N., Pons, F. and Cunillera, T. (2019). The different impact of a structured peer-assessment task in relation to university undergraduates' initial writing skills, Assessment \& Evaluation in Higher Education, 44(5), 653-663.

$\rightarrow$ Ramsden, P. (2003). Learning to Teach in Higher Education (2 ${ }^{\text {nd }}$ ed.). London: Routledge Falmer.

$\rightarrow$ Rede Eurydice (2009), Ensino superior na Europa 2009: evolução do processo de Bolonha.

$\rightarrow$ Rede Eurydice (2010). Estruturas dos sistemas de educação e formação na Europa. Portugal 2009-2010.

$\rightarrow$ Ryan, M. and Ryan, M. (2013). Theorising a model for teaching and assessing reflective learning in higher education, Higher Education Research \& Development, 32(2), 244-257.

$\rightarrow$ Rust, C. (2002). The impact of assessment on student learning: how can the research literature practically help to inform the development of departamental assessment strategies and learner-centred assessment practices?, Active Learning in Higher Education, 3(2), 145-158.

$\rightarrow$ Sambell, K. and McDowell, L. (1998). The construction of the hidden curriculum: messages and meanings in the assessment of student learning, Assessment and Evaluation in Higher Education, 23(4), 391-402.

$\rightarrow$ Shulman, L. (1998). Theory, Practice, and the Education of Professionals, The Elementary School Journal, 98(5), 511-526.

$\rightarrow$ Sluijsmans, D., Dochy, F. and Moerkerke, G. (1999). Creating a learning environment by using self, peer- and co-assessment, Learning Environments Research: An International Journal, 1(3), 293-319.

$\rightarrow$ Stachowiak-Kudła, M. (2012). Autonomia szkół wyższych a instytucjonalne mechanizmy zapewnienia jakości w Polsce i wybranych państwach europejskich. Warsaw: Difin. 
$\rightarrow$ Struyven, K., Dochy, F. and Janssens, S. (2003). Students' perceptions about new modes of assessment in higher education: A review. In: M. Segers, F. Dochy, E. Cascallar (eds.), Optimising new modes of assessment: In search of qualities and standard (pp. 171-223). Dordrecht: Kluwer Academic Publishers.

$\rightarrow$ Tang, S. (2002). School-based learning in initial teacher education. Cardiff: Cardiff University.

$\rightarrow$ Tang, S., Wong, A. and Cheng, M. (2012). Professional Learning in Initial Teacher Education: Vision in the Constructivist Conception of Teaching and Learning, Journal of Education for Teaching, 38(4), 435-451.

$\rightarrow$ Tang, S., Wong, A. and Cheng, M. (2016). Examining professional learning and the preparation of professionally competent teachers in initial teacher education, Teachers and Teaching, 22(1), 54-69.

$\rightarrow$ Tang, S., Wong, A., Li, D. and Cheng, M. (2019). Examining student teachers' engagement with the theory-practice link in initial teacher education, Journal of Education for Teaching, 45(2), 123-139.

$\rightarrow$ Taras, M. (2005). Assessment - summative and formative - some theoretical reflections, British Journal of Educational Studies, 53(4), 466-478.

$\rightarrow$ Thomas, D., Moore, R., Rundle, O, Emery, S., Greaves, R., Riele, K. and Kowaluk, A. (2019). Elaborating a framework for communicating assessment aims in higher education, Assessment \& Evaluation in Higher Education, 44(4), 546-564.

$\rightarrow$ Thorpe, M. (2000). Encouraging students to reflect as part of the assignment process: student responses and tutor feedback, Active Learning in Higher Education, 1(1), 79-92.

$\rightarrow$ Townsend, T. (2011). Searching High and Searching Low, Searching East and Searching West: Looking for Trust in Teacher Education, Journal of Education for Teaching, 37(4), 483-499.

$\rightarrow$ Turner, C. and Purpura, J. (2016). Learning-oriented assessment in second and foreign language classrooms. In: D. Tsagari, J. Baneerjee, Handbook of Second Language Assessment (pp. 255-272). Boston: De Gruyter Mouton.

$\rightarrow$ Valeeva, R. and Gafurov, I. (2017). Initial teacher education in Russia: connecting theory, practice and research, European Journal of Teacher Education, 40(3), 342-360.

$\rightarrow$ Van Nuland, S. (2011). Teacher Education in Canada, Journal of Education for Teaching, 37(4), 409-421.

$\rightarrow$ Vergés Bausili, A. (2018). From Piloting E-Submission to Electronic Management of Assessment (EMA): Mapping Grading Journeys, British Journal of Educational Technology, 49(3), 463.478. 
$\rightarrow$ Vickerman, P. (2009). Student perspectives on formative peer assessment: An attempt to deepen learning?, Assessment \& Evaluation in Higher Education, 34(2), 221-230.

$\rightarrow$ Villarroel, V., Bloxham, S., Bruna, D., Bruna, C. and Herrera-Seda, C. (2017). Authentic Assessment: Creating a Blueprint for Course Design, Assessment \& Evaluation in Higher Education, 43(5), 840-854.

$\rightarrow$ Wæge, K. and Haugaløkken, O. (2013). Research-based and hands-on practical teacher education: An attempt to combine the two, Journal of Education for Teaching, 39, 235-249.

$\rightarrow$ Webber, K. (2012). The Use of Learner-Centered Assessment in US Colleges and Universities, Research in Higher Education, 53(2), 201-228.

$\rightarrow$ Wicking, P. (2020). Formative assessment of students from a Confucian heritage culture: Insights from Japan, Assessment \& Evaluation in Higher Education, 45(2), 180-192.

$\rightarrow$ Wiliam, D. (2007). Keeping Learning on Track: Formative Assessment and the Regulation of Learning. In: F.K. Lester (ed.), Second Handbook of Mathematics Teaching and Learning (pp. 1053-1098). Greenwich: Information Age.

$\rightarrow$ Woolhouse, C. and Cochrane, M. (2015). Educational Policy or Practice? Traversing the Conceptual Divide between Subject Knowledge, Pedagogy and Teacher Identity in England, European Journal of Teacher Education, 38(1), 87-101.

$\rightarrow$ Yorke, M. (2007). Assessment, especially in the first year of higher education: Old principles in new wrapping?. Paper presented at the REAP international online conference on assessment design for learner responsibility, http://ewds. strath.ac.uk/REAP07

$\rightarrow$ Zimmerman, B. (2002). Becoming a self-regulated learner: An overview, Theory into Practice, 41(2), 64-70.

$\rightarrow$ Zimmermann, P., Flavier, E. and Méard, J. (2012). L'identité professionnelle des enseignants en formation initiale Spiral-E, Revue de Recherche en Éducation, $49,35-50$. 
